\title{
Investigation of Cardiovascular Endurance Levels of Sedentary High School Students*
}

\author{
Betül Akyol'1, Kayhan Söğüt ${ }^{2}$ \\ ${ }^{1}$ Inonu University, Turkey \\ ${ }^{2}$ Mehmet Salih Şirin Ortaokulu, Turkey \\ Correspondence: Betül Akyol, Inonu University, Turkey.
}

Received: February 26, 2018

Accepted: March 30, $2018 \quad$ Online Published: April 9, 2018

doi:10.11114/jets.v6i5.3039

URL: https://doi.org/10.11114/jets.v6i5.3039

\begin{abstract}
The aim of our study is to examine the cardiovascular endurance systems of sedentary high school students. The 112 sedentary individual was taken to the 1600 meter walking test run, and the 120 sedentary individual Harward step test. While both individuals were participating in the same test, weight, height, oxygen saturation, and heart rate of participants were measured before starting the test. As soon as the test is finished (recovery period), oxygen saturation and heart rate variability of individuals are measured at 1,3,5 minutes. All measured variables were analyzed and compared. Analysis of the data was done according to the SPSS statistical program and the significance level was accepted as $\mathrm{p}<0.05$. In the 1600 -meter walking test, it was observed that there was a significant difference in mean heart rate between males and females $\mathrm{p}<0.05$. There was a significant difference between the mean values of the time of completion of the $1600 \mathrm{~m}$ running test by males and females ( $\mathrm{p}<0.05)$. During the 1600 -meter walking and Harward step test recovery period, there was no difference in the participants' parameters. There was no significant difference between oxygen saturations at beginning, recovery 1 st, 3rd, and 5 th minutes in both tests. Significant differences were found between heart rate and oxygen saturation values (beginning, recovery 1st, 3rd, and 5th minutes) in the intra-group comparisons of both groups. Participants' heart rates began to increase with exercise, but remained above the initial heart rate level during recovery. Participants' body mass indexes were observed to be within normal values. We think that can be increased cardio respiratory and cardiovascular fitness levels and can been created lifelong exercise habits by regular exercise programs are given to Sedentary high school students. Thus, we believe that the young population can be prevented from getting sick by providing healthier, social, active individuals.
\end{abstract}

Keywords: cardiovascular endurance, sedentary life, 1600 m running walk test, Harward step test

\section{Introduction}

Ever since human beings have come to the world, they have been in constant change and development. One of the areas where this development and change has penetrated the most is technology. With the advancement of technology, new tools and machines have begun to be built and it has been observed that the work load of people on body strength has decreased. It has been understood that individual has started to immobilization because physical burden has decreased and instead of machine technology (Brown, 2014; Harari, 2017).

The inactive life situation brought the sedentary lifestyle to the individual. The sedentary life process is influenced in the deterioration of the body metabolism of the individual and also in the negative emotional state in spite of the spiritual direction (Kalyon, 1990). The state of cannot consume the energy received is emerging in individual who adopts a sedentary lifestyle. Unavailable energy comes to as excess weight in human metabolism (Harari, 2017; Kalyon, 1990). Overweight is known to negatively affect the cardiovascular system and negatively affect the individual's performance (Tremblay et al., 2010; Orkunoğlu, 1989).

It has been observed that many countries are trying to create lifelong sport habits to get rid of the sedan lifestyle and overweight. It has been understood that the hearts of individuals who make sporting habits regular and effective are stronger. It has also been understood through the results of previous research that it is the development of the

*This study was supported by the Scientific Research Projects Unit (BAP) of İnonu University. 
cardiovascular systems of individuals who are observed to have brought Body Mass Indexes to normal levels through regular exercises (Kalyon, 1990; Karatay, 2017; Lafay et al., 2016). It has also been observed that the positive changes in the spiritual structure of the individuals who play sports (Kalyon, 1990; Şekeroğlu et al., 1997).

\section{Materials and Methods}

9th, 10th, 11th, and 12th grade students in high school have attended to study. Sedentary 57 male, 55 female volunteers participated in the 1600-meter walking test, while sedentary 60 male and 60 female participated in the Harward step test. Each participant's weight and height measurements were measured before tests. Different tests were done on different days for the same person. Heart rate and oxygen saturations were measured and recorded by oximetry in the first, third, and fifth minutes after the test and before the test. The data were evaluated with the IBMSPSS Statistics 22.0 package program and the significance level was taken as $\mathrm{p}<0.05$. The groups were compared according to two Independent Sample T Tests. Intra-group comparisons were evaluated by the Friedman test.

\section{Results}

Table 1. 1600 m Walking Running Test, Comparing the Mean of Heart Rate Values of Men and Women

\begin{tabular}{llll}
\hline Start Heart rate (Pulse/ Min.) & $\mathbf{n}$ & $\mathbf{X} \pm$ SD & p \\
Male & 57 & $88.75 \pm 10.25$ & \\
Female & 55 & $94.90 \pm 11.74$ & .00 \\
Total & 112 & $91.77 \pm 11.38$ & \\
$\mathbf{1}^{\text {st } \text { Min. Start Heart rate (Pulse/ Min.) }}$ & & & \\
Male & 57 & $152.89 \pm 20.20$ & \\
Female & 55 & $152.89 \pm 23.49$ & .99 \\
Total & 112 & $152.89 \pm 21.78$ & \\
$\mathbf{3}^{\text {rd Min. Start Heart rate (Pulse/Min.) }}$ & & & \\
Male & 57 & $119.43 \pm 11.81$ & \\
Female & 55 & $122.98 \pm 12.96$ & .13 \\
Total & 112 & $121.17 \pm 12.46$ & \\
$\mathbf{5}^{\text {th } \text { Min. Start Heart rate (Pulse/ Min.) }}$ & & & \\
Male & 57 & $113.50 \pm 10.87$ & \\
Female & 55 & $116.96 \pm 12.23$ & .11 \\
Total & 112 & $115.20 \pm 11.63$ & \\
\hline
\end{tabular}

When the initial mean heart rate values were compared, there was a significant difference in heart rate averages between men and women $(\mathrm{p}<0.05)$, there was no significant difference in heart rate averages between 1st, 3rd, and 5th minute of recovery $(\mathrm{p}>0.05)$.

Table 2. Comparison of Mean Values of Finishing Times of $1600 \mathrm{~m}$ Walking Test in Men and Women

\begin{tabular}{lccl}
\hline $\mathbf{1 6 0 0}$ m test finish (min. ) & $\mathbf{n}$ & $\mathbf{X} \pm$ SD & $\mathbf{p}$ \\
Male & 57 & $10.48 \pm 1.26$ & \\
Female & 55 & $12.74 \pm 1.01$ & .00 \\
Total & 112 & $11.59 \pm 1.61$ & \\
\hline
\end{tabular}

It was observed that there was significant difference between males and females because $p<0.05$ is result of mean values of $1600 \mathrm{~m}$ walking test completion times.

Table 3. Harward Stage Test, Comparison of Mean Values of Heart Rate Values of Men and Women

\begin{tabular}{llll}
\hline Start Heart rate (Pulse/min.) & $\mathbf{n}$ & $\mathbf{X} \pm$ SD & $\mathbf{p}$ \\
Male & 60 & $93.18 \pm 12.89$ & \\
Female & 60 & $95.63 \pm 16.06$ & .36 \\
Total & 120 & $94.40 \pm 14.55$ & \\
$\mathbf{1}^{\text {st }}$ min. Start Heart rate (Pulse/min.) & & & \\
Male & 60 & $175.31 \pm 15.59$ & \\
Female & 60 & $177.10 \pm 15.11$ & .58 \\
Total & 120 & $176.20 \pm 15.32$ & \\
$\mathbf{3}^{\text {rd }}$ min. Start Heart rate (Pulse/min.) & & & \\
Male & 60 & $124.18 \pm 14.33$ & \\
Female & 60 & $128.73 \pm 16.63$ & .08 \\
Total & 120 & $126.45 \pm 15.63$ & \\
$\mathbf{5}^{\text {th }}$ min. Start Heart rate (Pulse/min.) & & & \\
Male & 60 & $117.31 \pm 13.69$ & \\
Female & 60 & $119.90 \pm 15.44$ & .33 \\
Total & 120 & $118.60 \pm 14.59$ & \\
\hline & & & \\
& &
\end{tabular}


There was no significant difference in heart rate averages between the first, third, and fifth minute of recovery $(\mathrm{p}>0.05)$.

Table 4. $1600 \mathrm{~m}$ Walking Test, Comparison of Mean Values of Oxygen Saturation in Male and Female

\begin{tabular}{llll}
\hline Start $\left(\% \mathbf{S p O}_{2}\right)$ & $\mathbf{n}$ & $\mathbf{X} \pm \mathbf{S D}$ & $\mathbf{p}$ \\
Male & 57 & $97.05 \pm 1.39$ & \\
Female & 55 & $97.05 \pm 1.06$ & .51 \\
Total & 112 & $97.05 \pm 1.23$ & \\
$\mathbf{1}^{\text {st }}$ min. $\left(\% \mathbf{S p O}_{2}\right)$ & & & \\
Male & 57 & $94.26 \pm 1.83$ & \\
Female & 55 & $94.41 \pm 2.58$ & .65 \\
Total & 112 & $94.33 \pm 2.22$ & \\
$\mathbf{3}^{\text {rd }}$ min. $\left(\% \mathbf{S p O}_{2}\right)$ & & & \\
Male & 57 & $94.85 \pm 1.57$ & \\
Female & 55 & $95.36 \pm 1.86$ & .12 \\
Total & 112 & $95.10 \pm 1.73$ & \\
$\mathbf{5}^{\text {th }}$ min. $\left(\boldsymbol{\%} \mathbf{S p O}_{\mathbf{2}}\right)$ & & & \\
Male & 57 & $95.31 \pm 1.99$ & \\
Female & 55 & $95.65 \pm 1.63$ & .32 \\
Total & 112 & $95.48 \pm 1.82$ & \\
\hline
\end{tabular}

There was no significant difference in oxygen saturation averages between the first, third, and fifth minute of recovery $(\mathrm{p}>0.05)$.

Table 5. Harward Step Test, Comparison of Oxygen Saturation Mean Values for Men and Women

\begin{tabular}{|c|c|c|c|}
\hline Start $\left(\% \mathrm{SpO}_{2}\right)$ & $\mathbf{n}$ & $\mathrm{X} \pm \mathrm{SD}$ & $\mathbf{p}$ \\
\hline Male & 60 & $96.53 \pm 1.48$ & \\
\hline Female & 60 & $96.23 \pm 1.46$ & .26 \\
\hline Total & 120 & $96.38 \pm 1.47$ & \\
\hline \multicolumn{4}{|c|}{$\mathbf{1}^{\text {st }} \min .\left(\% \mathrm{SpO}_{2}\right)$} \\
\hline Male & 60 & $94.58 \pm 1.84$ & \\
\hline Female & 60 & $95.20 \pm 1.87$ & .07 \\
\hline Total & 120 & $94.89 \pm 1.87$ & \\
\hline \multicolumn{4}{|c|}{$3^{\text {rd }} \min .\left(\% \mathrm{SpO}_{2}\right)$} \\
\hline Male & 60 & $95.21 \pm 1.89$ & \\
\hline Female & 60 & $95.26 \pm 1.69$ & .97 \\
\hline Total & 120 & $95.24 \pm 1.79$ & \\
\hline \multicolumn{4}{|c|}{$5^{\text {th }} \min .\left(\% \mathrm{SpO}_{2}\right)$} \\
\hline Male & 60 & $95.40 \pm 1.42$ & \\
\hline Female & 60 & $95.15 \pm 1.69$ & .38 \\
\hline Total & 120 & $95.27 \pm 1.56$ & \\
\hline
\end{tabular}

There was no significant difference in oxygen saturation averages between the first, third, and fifth minute of recovery $(\mathrm{p}>0.05)$.

Table 6. $1600 \mathrm{~m}$ Walking Test, mean values of BMI for participating males and females

\begin{tabular}{lcl}
\hline BMI $\left(\mathbf{k g} / \mathbf{m}^{2}\right)$ & $\mathbf{n}$ & $\mathbf{X} \pm$ SD \\
Male & 57 & $22.03 \pm 2.49$ \\
Female & 55 & $22.10 \pm 2.67$ \\
Total & 112 & $22.07 \pm 2.57$
\end{tabular}

Table 7. BMI Mean Values of Male and Female Participating in Harward Step Test

\begin{tabular}{lll}
\hline BMI $\left(\mathbf{k g} / \mathbf{m}^{2}\right)$ & $\mathbf{N}$ & $\mathbf{X} \pm$ SD \\
Male & 57 & $22.14 \pm 2.49$ \\
Female & 55 & $22.07 \pm 2.58$ \\
Total & 112 & $22.11 \pm 2.52$ \\
\hline
\end{tabular}


Table 8. $1600 \mathrm{~m}$ Walking run Test, Comparison of Men's Beginning, 1st, 3rd, 5th Minute Heart Rate Values

\begin{tabular}{lcclll}
\hline & $\mathbf{N}$ & $\mathbf{X} \pm$ SD & Order averages & $\mathbf{X}^{\mathbf{2}}$ & $\mathbf{p}$ \\
Start heart rate & 57 & $88.75 \pm 10.25$ & 1.04 & & \\
$\mathbf{1}^{\text {st }}$ min. heart rate & 57 & $152.89 \pm 20.20$ & 4.00 & 160.65 & 0.00 \\
$\mathbf{3}^{\text {rd }}$ min. heart rate & 57 & $119.43 \pm 11.81$ & 2.86 & & \\
$\mathbf{5}^{\text {th }}$ min. heart rate & 57 & $113.50 \pm 10.87$ & 2.11 & & \\
\hline
\end{tabular}

*p $<0.05$

In Table 8, the heart rate variables measured in the men's $1600 \mathrm{~m}$ walking test were compared within themselves. The comparisons were made according to the Friedman test. As a result of analysis, there was a significant correlation between heart rate values at all times because $\mathrm{p}<0.05$ was the case.

Table 1. $1600 \mathrm{~m}$ Walking run Test, Comparison of Women's Beginning, 1st, 3rd, 5th Minute Heart Rate Values

\begin{tabular}{lcllll}
\hline & $\mathbf{N}$ & $\mathbf{X} \pm \mathbf{S S}$ & Order averages & $\mathbf{X}^{\mathbf{2}}$ & $\mathbf{p}$ \\
\hline Start heart rate & 55 & $94.90 \pm 11.74$ & 1.08 & & \\
$\mathbf{1}^{\text {st }}$ min. heart rate & 55 & $152.89 \pm 23.49$ & 3.95 & \multirow{2}{*}{146.00} & 0.00 \\
$\mathbf{3}^{\text {rd }}$ min. heart rate & 55 & $122.98 \pm 12.96$ & 2.85 & & \\
$\mathbf{5}^{\text {th }}$ min. heart rate & 55 & $116.96 \pm 12.23$ & 2.12 & & \\
\hline
\end{tabular}

*p $<0.05$

In Table 9, the heart rate variables measured in the women's $1600 \mathrm{~m}$ walking test were compared within themselves. The comparisons were made according to the Friedman test. As a result of analysis, there was a significant correlation between heart rate values at all times because $\mathrm{p}<0.05$ was the case.

Table 10. $1600 \mathrm{~m}$ Walking run Test, Comparison of Men's Beginning, 1st, 3rd, 5th Minute Oxygen Saturation Values

\begin{tabular}{|c|c|c|c|c|c|}
\hline & $\mathbf{N}$ & $\mathrm{X} \pm \mathrm{SD}$ & Order averages & $\mathbf{X}^{2}$ & $\mathbf{p}$ \\
\hline Start \% $\mathrm{SpO}_{2}$ & 57 & $97.05 \pm 1.39$ & 3.48 & \multirow{4}{*}{60.89} & \multirow{4}{*}{0.00} \\
\hline $1^{\text {st }} \min . \% \mathrm{SpO}_{2}$ & 57 & $94.26 \pm 1.83$ & 1.83 & & \\
\hline $3^{\text {rd }} \min . \% \mathrm{SpO}_{2}$ & 57 & $94.85 \pm 1.57$ & 2.18 & & \\
\hline $5^{\text {th }} \min . \% \mathrm{SpO}_{2}$ & 57 & $95.31 \pm 1.99$ & 2.51 & & \\
\hline
\end{tabular}

$* \mathrm{p}<0.05$

In Table 10, the $\% \mathrm{SpO}_{2}$ variables measured in the men's $1600 \mathrm{~m}$ walking test were compared within themselves. The comparisons were made according to the Friedman test. As a result of analysis, there was a significant correlation between oxygen saturation values at all times because $\mathrm{p}<0.05$ was the case.

Table 2. $1600 \mathrm{~m}$ Walking run Test, Comparison of Women's Beginning, 1st, 3rd, 5th Minute Oxygen Saturation Values

\begin{tabular}{lcclll}
\hline & $\mathbf{N}$ & $\mathbf{X} \pm$ SD & Order averages & $\mathbf{X}^{\mathbf{2}}$ & $\mathbf{p}$ \\
\hline Start \% SpO & 55 & $97.05 \pm 1.06$ & 3.29 & & \\
$\mathbf{1}^{\text {st }} \mathbf{m i n} . \% \mathbf{S p O}_{2}$ & 55 & $94.41 \pm 2.58$ & 1.86 & 39.32 & 0.00 \\
$\mathbf{3}^{\text {rd }}$ min.\% SpO & 55 & $95.36 \pm 1.86$ & 2.34 & & \\
$\mathbf{5}^{\text {th }}$ min.\% $\mathbf{S p O}_{\mathbf{2}}$ & 55 & $95.65 \pm 1.63$ & 2.51 & & \\
\hline
\end{tabular}

$* \mathrm{p}<0.05$

In Table 11, the $\% \mathrm{SpO}_{2}$ variables measured in the women's $1600 \mathrm{~m}$ walking test were compared within themselves. The comparisons were made according to the Friedman test. As a result of analysis, there was a significant correlation between oxygen saturation values at all times because $\mathrm{p}<0.05$ was the case.

Table 12. Harward Step Test, Comparison of Men's Beginning, 1st, 3rd, 5th Minute Heart Rate Values

\begin{tabular}{lccccc}
\hline & $\mathbf{N}$ & $\mathbf{X} \pm$ SD & Order averages & $\mathbf{X}^{\mathbf{2}}$ & $\mathbf{p}$ \\
\hline Start heart rate & 60 & $93.18 \pm 12.89$ & 1.02 & & \\
$\mathbf{1}^{\text {st }}$ min. heart rate & 60 & $175.31 \pm 15.59$ & 4.00 & \multirow{2}{*}{172.40} & 0.00 \\
$\mathbf{3}^{\text {rd }}$ min. heart rate & 60 & $124.18 \pm 14.33$ & 2.88 & & \\
$\mathbf{5}^{\text {th }}$ min. heart rate & 60 & $117.31 \pm 13.69$ & 2.10 & & \\
\hline
\end{tabular}

$* \mathrm{p}<0.05$

In Table 12, the heart rate variables measured in the men's Harward step test were compared within themselves. The 
comparisons were made according to the Friedman test. As a result of analysis, there was a significant correlation between heart rate values at all times because $\mathrm{p}<0.05$ was the case.

Table 13. Harward Step Test, Comparison of Women's Beginning, 1st, 3rd, 5th Minute Heart Rate Values

\begin{tabular}{lccccc}
\hline & $\mathbf{N}$ & $\mathbf{X} \pm$ SD & Order averages & $\mathbf{X}^{\mathbf{2}}$ & $\mathbf{p}$ \\
\hline Start heart rate & 60 & $95.63 \pm 16.06$ & 1.08 & & \\
$\mathbf{1}^{\text {st }}$ min. heart rate & 60 & $177.10 \pm 15.11$ & 3.97 & \multirow{2}{*}{160.58} & 0.00 \\
$\mathbf{3}^{\text {rd }}$ min. heart rate & 60 & $128.73 \pm 16.63$ & 2.86 & & \\
$\mathbf{5}^{\text {th }}$ min. heart rate & 60 & $119.90 \pm 15.44$ & 2.09 & & \\
\hline
\end{tabular}

*p $<0.05$

In Table 13, the heart rate variables measured in the women's Harward step test were compared within themselves. The comparisons were made according to the Friedman test. As a result of analysis, there was a significant correlation between heart rate values at all times because $\mathrm{p}<0.05$ was the case.

Table 14. Harward Step Test, Comparison of Men's Beginning, 1st, 3rd, 5th Minute Oxygen Saturation Values

\begin{tabular}{lcclll}
\hline & $\mathbf{N}$ & $\mathbf{X} \pm$ SD & Order averages & $\mathbf{X}^{\mathbf{2}}$ & $\mathbf{p}$ \\
\hline Start \% SpO & 60 & $96.53 \pm 1.48$ & 3.38 & & \\
$\mathbf{1}^{\text {st }} \mathbf{m i n} . \% \mathbf{S p O}_{2}$ & 60 & $94.58 \pm 1.84$ & 1.87 & 52.41 & 0.00 \\
$\mathbf{3}^{\text {rd }} \mathbf{m i n} \% \mathbf{S p O}$ & 60 & $95.21 \pm 1.89$ & 2.42 & & \\
$\mathbf{5}^{\text {th }} \mathbf{m i n} \% \mathbf{S p O}$ & 60 & $95.40 \pm 1.42$ & 2.34 & & \\
\hline
\end{tabular}

*p $<0.05$

In Table 14, the $\% \mathrm{SpO}_{2}$ variables measured in the men's Harward Step test were compared within themselves. The comparisons were made according to the Friedman test. As a result of analysis, there was a significant correlation between oxygen saturation values at all times because $\mathrm{p}<0.05$ was the case.

Table 15. Harward Step Test, Comparison of Women's Beginning, 1st, 3rd, 5th Minute Oxygen Saturation Values

\begin{tabular}{lcclll}
\hline & $\mathbf{N}$ & $\mathbf{X} \pm \mathbf{S D}$ & Order averages & $\mathbf{X}^{\mathbf{2}}$ & $\mathbf{p}$ \\
\hline Start \% SpO & 60 & $96.23 \pm 1.46$ & 3.11 & & \\
$\mathbf{1}^{\text {st }} \mathbf{m i n}$ \% $\mathbf{S p O}_{2}$ & 60 & $95.20 \pm 1.87$ & 2.38 & 21.35 & 0.00 \\
$\mathbf{3}^{\text {rd }} \mathbf{m i n} \% \mathbf{S p O}$ & 60 & $95.26 \pm 1.69$ & 2.28 & & \\
$\mathbf{5}^{\text {th }} \mathbf{m i n} \% \mathbf{S p O}$ & 60 & $95.15 \pm 1.69$ & 2.23 & & \\
\hline
\end{tabular}

*p $<0.05$

In Table 15, the $\% \mathrm{SpO}_{2}$ variables measured in the women's Harward Step test were compared within themselves. The comparisons were made according to the Friedman test. As a result of analysis, there was a significant correlation between oxygen saturation values at all times because $\mathrm{p}<0.05$ was the case.

\section{Discussion and Conclusion}

The aim of the study was to determine the cardiovascular endurance status of high school graduate students with 1600 m running-walk test and Harward step test. Heart rates and oxygen saturations of men and women participating in the 1600-meter walking test were evaluated before testing began. Men's heart rates are lower than women's. It was observed that there was no significant relationship in the comparison of heart rate at 1st, 3rd and 5th minutes of recovery period. We think that women have a higher heart rate before the test and that they reach a similar heart rate to that of men during the recovery period due to women are excited before the test. It was thought that sedentary men and women are in similar cardiovascular conditions because of men and women had no significant difference in heart rate conditions measured in the Harward step test and similarity with the results of the 1600-meter test.

Studies conducted by Kalkavan A. et. al. in 1996 have shown that durability condition of sedentary people are less powerful than athletes. Studies conducted by Kin A. et al. In 1996 found that the cardiac endurance status of sedentary individuals was lower than athletes (Kalkavan et al., 1996).

By Çolakoğlu FF, Şenel Ö. In 2003, a regular exercise program was applied to sedentary individuals. As a result of the application, it was observed that there was a significant decrease in individual's weight and resting heart rate (Çolakoğlu et al., 2003).

In the study conducted by Karacan S. et al. In 2004, regular exercise program for 3 months was applied to sedentary individuals. When the initial measured variables were compared after exercise program, were observed a significant decrease in weight, BMI and resting heart rate and a significant increase in aerobic capacity (Women et al., 2004).

In the studies conducted by Zorba E. and colleagues in 2004 on sedentary individuals, a grub practiced a regular exercise program but did not apply the other group exercise program. Body weight, resting heart rate, body fat ratio, body mass 
index (BMI) did not change in group exercising after 2.5 months. It was observed that body function was also positively influenced when a significant difference was observed in body masses exercising regularly for 2.5 months (Zorba et al., 2004). In the study conducted by Bicer Y. and colleagues in 2008, sedentary individuals were exercised regularly for 12 weeks. Variables were measured before the program started and after the program was finished. In the case of heart rate, it was seen as a significant development in the positive direction (Biçer \& Kaldırımcı, 2008).

In our study, it is normal that there was a significant difference in heart rate comparisons between men and women in the beginning, 1st, 3rd, and 5th minutes of the test in both tests and heart rates before the test are lower than after the test. In healthy sedentary people, heart rate should increase with exercise and reach to normal values in recovery phase. In our study, it was observed that the heart rate increased in the male and female group and the heart rate decreased in the recovery period but the resting heart rate could not be reached. This can be explained by the fact that the cardiovascular capacities of sedentary persons are lower than those who are trained. Because with training, occurs a decrease in the rate of heart. This means that the trained heart will work less for the same job than for the non-trained heart (Sönmez, 2002).

When the studies are examined, it is observed that regular exercise programs are applied to the individuals who live in the sedentary trait, and that the cardiovascular systems are improved in positive direction. In our study, we think that the heart rates increase in order that the individuals in the sedentary feature can get enough oxygen to the working muscles. It can be said based on the previous studies that the groups we study can give different responses to the same tests if regular exercise programs are given. That is, we think that individuals who develop cardiovascular system through regular exercises will be able to finish the tests with lower heart rate (Kalkavan et al., 1996; Çolakoğlu et al, 2003; Women et al., 2004; Zorba et al., 2004; Biçer et al, 2008).

Ozdal and his colleagues performed 22 voluntary male subjects in 12-14 age range in 2014, 11 male individuals regularly exercise while 11 male individuals are living sedentary. 2-month planned and programmed aerobic exercise program was administered to individuals. The $\mathrm{SpO}_{2}$ of the individual was measured before and after the exercise. When the variables before and after exercise were examined, aerobic exercise increased $\mathrm{SpO}_{2}$ in both the athlete group and the sedentary group (Özdal et al., 2014).

Sharma and Acharya performed a work on the sedentary people and 45 people were given yoga exercises for 3 months and 45 people of the control group were not exercised. $\mathrm{SpO}_{2}$ values of both groups were measured at the beginning and at the end of the work. At the end of 3 months, the oxygen saturation values of the group of Yoga exercises increased significantly, but the oxygen saturation values of the control group did not change (Sharma et al, 2018).

In our study, oxygen saturation variables were measured at 1, 3,5 minutes before men and women started the 1600 meter walking test and after the test was finished. It was observed that there was no significant difference between male and female as a result of comparison. The same was true for the results of the Harward step test. When the responses to the two tests were evaluated, it was thought that male and female subjects gave common metabolic responses due to sedentary experience.

In our study, we think that there is a significant difference between men and women in the beginning, 1st, 3rd, and 5th minute oxygen saturation comparisons in both tests, because of increased oxygen requirement in the tissues and muscles during exercise.

In the study conducted by Kin A. et al. In 1996, while some of the sedentary individuals were being regularly exercised for 2 months; other group exercise program didn't applied. The variables were compared before the exercise started and after the exercise was finished. It was observed that there was a significant difference between the $\mathrm{VO}_{2}$ max of group exercising and the group who did not exercise. This observation shows that cardiovascular systems of regularly sporting individuals are stronger than those who do not (Koşar et al, 1996).

Colakoğlu FF. In 2003, a regular exercise program was applied to sedentary individuals for 2 months. The variables were measured before starting the test and after the test were finished. There was a significant increase in $\mathrm{VO}_{2} \max$ (Çolakoğlu, 2003).

In the study conducted by Yigit $\mathrm{O}$. and his colleagues in 2013, a regular exercise program was applied in sedentary individuals for 3 months. The variables were measured before starting the test and after the test were finished. It was observed that $\mathrm{VO}_{2}$ max variable increased (Yiğit et al., 2013).

Sekeroglu MR. and colleagues observed in 1997 that individuals exercising were less likely to have heart disease than sedentary people (Şekeroğlu et al., 1997).

When all these studies are examined, it has been shown that individuals exercising regularly have an increase in oxygen saturation and $\mathrm{VO}_{2}$ max level. The increase in $\mathrm{VO}_{2}$ max level and oxygen saturation also means that the cardiovascular system develops.

University students, Physical-motoric values were examined as a pre and post-test in the Tae-Bo aerobic exercise 
program. The body weight and body fat percentage of the exercise group were significantly decreased after the test (Tekin et al., 2014).

In a study conducted by Agbuba B. and colleagues in 2007 to investigate the relationship between primary school students' performance of 20-meter shuttle running test (aerobic capacity) and Body Mass Index (BMI), a negative correlation was found between aerobic capacity and Body Mass Indexes (BMI) and this correlation was shown to be statistically significant (Ağbuba et al., 2007).

In our study, BMI values of men and women were normal values. We think that the average values of men's finishing time of the $1600 \mathrm{~m}$ running walk test are shorter than women's test completion times because women want to continue to slow down during the test. When the characteristics of the sedentary individuals are examined, it is observed that these values will follow negative trend by the effect of aging and inactivity. We also believe that negative follow-up BMI will adversely affect aerobic capacity and increase the risk of cardiovascular disease.

As a result; in the community, sedentary individuals should be taught regular exercise programs, the importance of doing sports, and sedentary individuals should be encouraged to exercise lifelong. Thus, we believe that sedentary individuals can increase their cardio respiratory and cardiovascular suitability levels and prevent diseases that may lead to healthier individuals in the future, and impair general health and social cohesion.

\section{References}

Ağbuba, B., Konukman, F., Yılmaz, İ., Köklü, Y., \& Alemdaroğlu, U. (2007). Investigation of the relationship between aerobic capacities and body mass indexes of children aged 8-12 years. Journal of Sports Sciences, 18, 137-146.

Barnes, A. S. (2012). Obesity and Sedentary Lifestyles. Texas Heart Institute Journal, 39(2), 224-227.

Biçer, Y., \& Kaldırımcı, M. (2008). Effects of three-month aerobic and weight-training aerobic exercise on the blood pressure, heart rate and some blood parameters of sedentary women. Journal of Physical Education and Sport Sciences, 10(2), 46-54.

Brown, G. (2014). The Effects of Values and the Presence of a Mobile Phone on Friendship Interactions. Masters thesis, Western Washington University; Bellingham.

Çolakoğlu, F. F. (2003). Effects of 8-Week Run Walking exercise on physiological, motoric and somatotype values in sedentary middle-aged obese women. Gazi University, Gazi Education Faculty Journal, 23(3), 275-290.

Ghildiyal, R. (2015). Role of sports in the development of an individual and role of psychology in sports. Mens Sana Monogr, 13(1), 165-170. https://doi.org/10.4103/0973-1229.153335

Harari, Y. N. (2017). Sapiens: Gods From Animals. Ertuğrul Genç (Çev.). İstanbul: Kolektip Kitap.

He, X. Z., \& Baker, D. W. (2004). Body Mass Index, Physical Activity, and the Risk of Decline in Overall Health and Physical Functioning in Late Middle Age. American Journal of Public Health,94(9), 1567-1573. https://doi.org/10.2105/AJPH.94.9.1567

Inyang, M., \& Stella, O. O. (2015). Sedentary Lifestyle: Health Implications. IOSR Journal of Nursing and Health Science, 4(2), 20-25. https://doi.org/10.9790/1959-04212025

Kalyon, T. A. (1990). Sportsman Health and Sports Injuries. (1. Bask1). Ankara: Gata Basımevi.

Kang, S. J., Kim, E., \& Ko, K. J. (2016). Effects of aerobic exercise on the resting heart rate, physical fitness, and arterial stiffness of female patients with metabolic syndrome. Journal of Physical Therapy Science, 28(6), 17641768. https://doi.org/10.1589/jpts.28.1764

Kim, J. H., Choe, Y. R., Song, M. K., Choi, I. S., \& Han, J. Y. (2017). Relationship Between Post-exercise Heart Rate Recovery and Changing Ratio of Cardiopulmonary Exercise Capacity. Ann. Rehabil. Med., 41(6), 1039-1046. https://doi.org/10.5535/arm.2017.41.6.1039

Kin, A., Koşar, A., \& Tuncel, N. (1996). Comparing the effect of 8-week step and aerobic dance on the physical fitness of college women. Sport Science Journal, 7(3), 21-31.

Lafay, O., \& Audouy, H. (2016). Methode de Musculation: Muscle Development Methods. Hadiye Deniz Ülker (Çev.). İstanbul, Pegasus Yayıncılık.

Lee, B. A., Oh, D. J. (2015). Effect of regular swimming exercise on the physical composition, strength, and blood lipid of middle-aged women. Journal of Exercise Rehabilitation, 11(5), 266-271. https://doi.org/10.12965/jer.150242 
Leslie, I. Katzel, M. D., John, D., Sorkin, M. D., Jerome, L., \& Fleg, M. D. (2001). A comparison of longitudinal changes in aerobic fitness in older endurance athletes and sedentary Men. Journal of American Geriatrics Society, 49(12), 1657-1664. https://doi.org/10.1111/j.1532-5415.2001.49276.x

Orkunoğlu, O. (1989). Power Development at Sport. (2. Baskı). Ankara: Gökçe Kitabevi.

Özdal, M., Dağlıŏlu, Ö., Demir, T., \& Özkul, N. (2014). Effect of aerobic exercise on arterial hemoglobin oxygen saturation. Sports and Performance Research Journal, 5(1), 27-34.

Şekeroğlu, M. R., Aslan,R., Tarakçığlu, M., \& Kara, M. (1997). The effects of acute and programmed exercise on serum apolipoproteins and lipids in sedentary men. General Medical Journal, 7(1), 5-8.

Sharma, M., \& Acharya, A. (2018). Effect of yogic exercise on oxygen satüration level in chronic smokers. International Journal of Scientific Research, 7(1).

Sönmez, G. T. (2002). Exercise and Sports Physiology. (4. print). İstanbul: Ata Ofset Matbaacılık.

Tiruneh, G. (2009). One substantial finding of this study was that the duration of exercise was that matters in lowering or maintaining the BMI of undergraduate-college students. International Journal On Disability and Human Development, 8(3), 267-275. https://hdl.handle.net/10101/npre.2009.2758.4

Tremblay, M. S., Colley, R. C., Saunders, T. J., Healy, G. N., \& Owen, N. (2010). Physiological and health implications of a sedentary lifestyle. Appl. Physiol. Nutr. Metab., 35, 725-740. https://doi.org/10.1139/H10-079

Women, M., Karacan, S., Çolakoğlu, F. F., \& Erol, A. E. (2004). Effects of aerobic exercise on some physical fitness values in obese middle-aged women and menopausal women. Erciyes University Health Sciences Journal, 13, $35-42$.

Yiğit, T., Kolukısa, Ş., \& Aydoğan, A. (2013). Investigation of the physiological changes of women performing sports for recreational purposes. Sport and Performance Research Journal, 4(1), 17-22.

Zorba, E., Babayiğit, G. İ., Saygın, Ö., İrez, G., \& Karacabey, K. (2004). Investigating the effect of a 10-week training program for some physical fitness parameters in the ages between 65 and 85 years. F. U. Health Sciences Journal, $18,229-234$.

\section{Copyrights}

Copyright for this article is retained by the author(s), with first publication rights granted to the journal.

This is an open-access article distributed under the terms and conditions of the Creative Commons Attribution license which permits unrestricted use, distribution, and reproduction in any medium, provided the original work is properly cited. 